\title{
Virtualization of science education: a lesson from the COVID-19 pandemic
}

\author{
Sandipan Ray $^{1}\left[\right.$ D $\cdot$ Sanjeeva Srivastava ${ }^{2}$
}

Received: 7 May 2020 / Revised: 18 May 2020 / Accepted: 23 May 2020 / Published online: 31 May 2020

(c) Springer Nature Singapore Pte Ltd. 2020

\begin{abstract}
The whole world is currently running through a critical stage of a novel coronavirus outbreak known as COVID-19. This infectious agent severe acute respiratory syndrome coronavirus 2 (SARS-CoV-2) has recently emerged as a human pathogen. This viral respiratory disease has spread around almost the entire world and already caused several thousand deaths within just a few months. COVID-19 poses a global health emergency, and the World Health Organization (WHO) declared it a pandemic.
\end{abstract}

Nowadays, e-learning and virtual labs have gained substantial popularity in science education. Amid the COVID-19 shutdowns, regular in-person classroom teaching and lab courses are suspended in several countries worldwide. In this scenario, virtual classes and online resources could serve more effectively as a possible alternative way of learning science from home.

\section{Educational systems moving into a virtual environment}

Due to the extremely contagious nature of this novel pathogen, social distancing and lockdowns became inevitable to prevent its rapid transmission at the community level (Anderson et al. 2020). Consequently, like most of the other professional activities, every day in-campus teaching and lab courses are suspended in numerous schools, colleges, and universities worldwide for an indefinite period. Nevertheless, the radical progress in modern information technology allows us to remain well connected while working from

Sandipan Ray

sandipan.ray@cantab.net

Sanjeeva Srivastava

sanjeeva@iitb.ac.in

1 Department of Systems Pharmacology and Translational Therapeutics, Perelman School of Medicine, University of Pennsylvania, Philadelphia, PA 19104, USA

2 Department of Biosciences and Bioengineering, Indian Institute of Technology Bombay, Mumbai 400076, India home. Educational administrators are now working hard to ensure that the teaching curriculums and students' education, though disrupted, should not halt entirely during this crisis period. Many esteemed institutes and universities are trying to circumvent this crisis by moving the essential educational missions into a virtual environment. To this end, the remote learning approaches including online courses, live streaming, virtual teaching, and simulated labs are serving as an excellent alternative means of learning science from home while staying at a safe distance (Fig. 1).

\section{Online and remote learning in science}

Over the last few decades, there has been a radical transformation in the goals and methods of science teaching in biology as the "Problem-based learning" emerged effectually where a problem to be solved as a part of the teaching course rather than only facts to be mastered (DiCarlo 2006; Wood 2001). Online learning and virtual teaching are emerging as new avenues for science and engineering education and it has accelerated the spread of educational resources globally (Hunter 2015; Waldrop 2013a). In particular, distance education and online learning approaches are proven to be more effective in the resource-limited developing countries, where the numbers of students are much higher than the available well-experienced teachers or highly equipped educational institutes and laboratories (Srivastava et al. 2013; Ray et al. 2016). The massive open online courses (MOOCs) for science, engineering, and technology education received large popularity in many countries (Waldrop 2013a; King et al. 2014), although there are some weighty glitches observed in terms of their completion rates and ability to reach the 


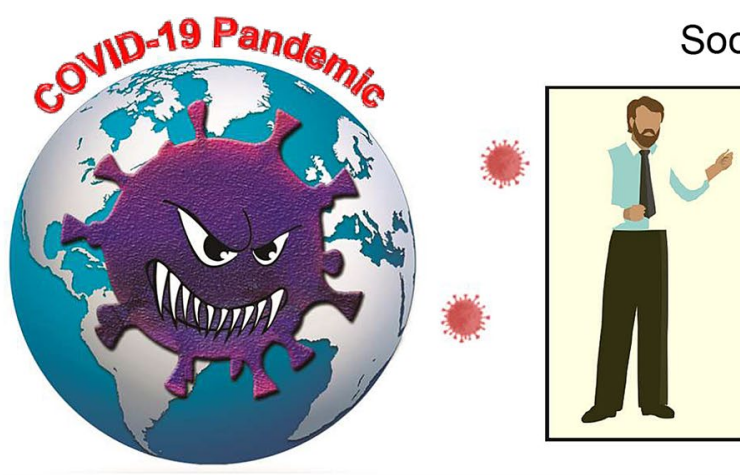

Social distancing and lockdowns
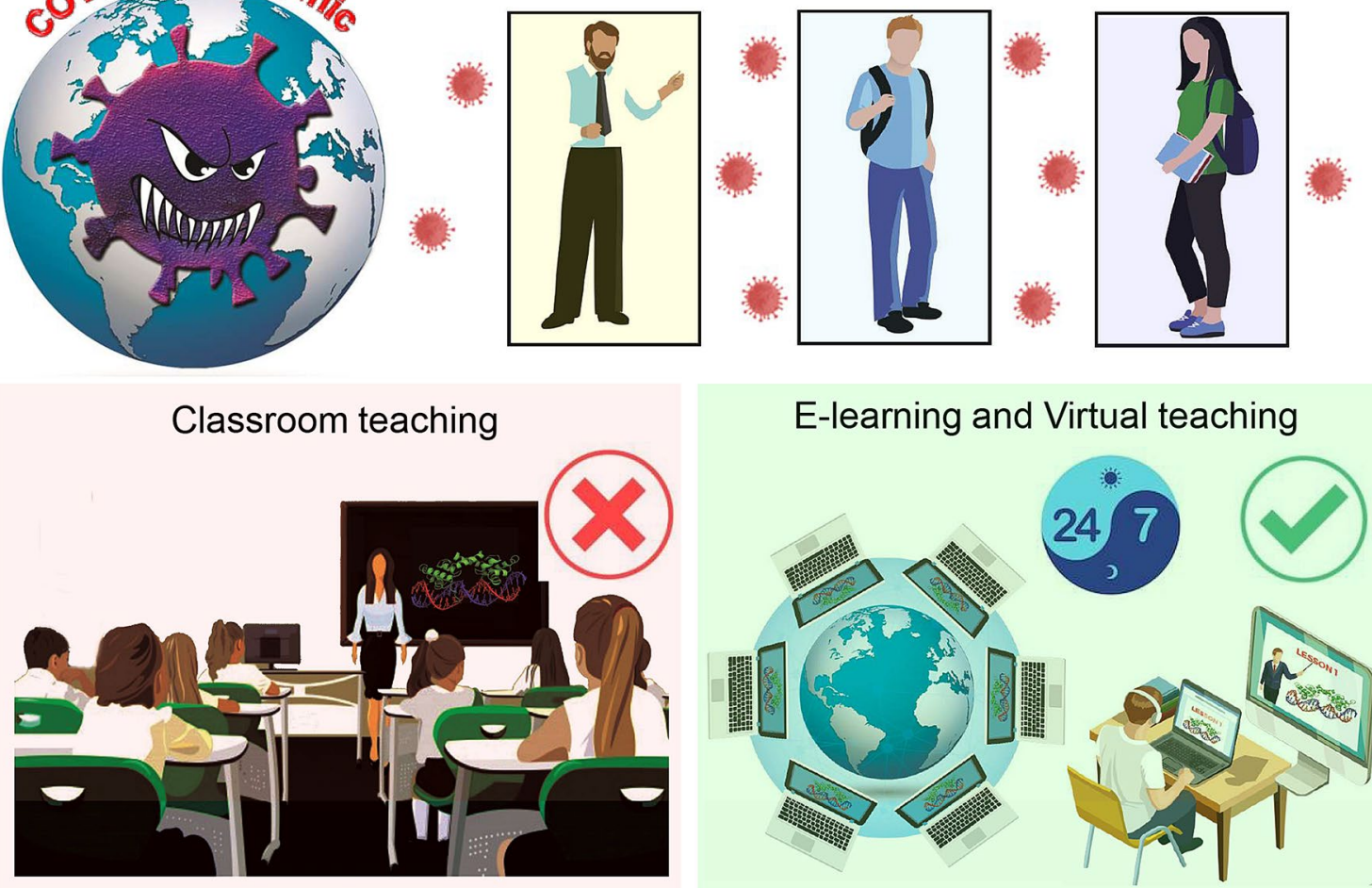

\section{E-learning and Virtual teaching}

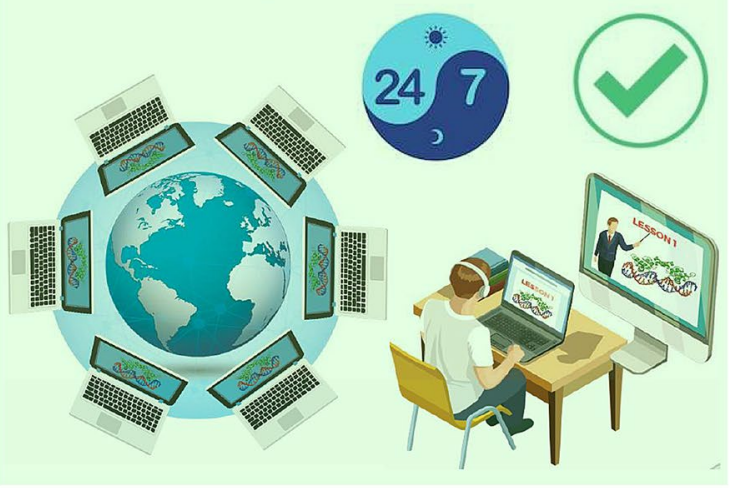

Fig. 1 Science education from home amid coronavirus shutdowns. Amid the COVID-19 shutdowns, in-person classroom teaching and laboratory courses are suspended worldwide for a significant dura-

tion. In this crisis period, e-learning resources, virtual lectures, and simulated labs could be excellent alternative ways of learning science from home

general population or non-traditional and disadvantaged learners (Hansen and Reich 2015; Emanuel 2013).

Overall, high-quality online learning resources and video lectures are certainly beneficial for regular school, college, and university level students who are looking for evolving their careers. Further, live streaming of sessions by the instructors could reach out to a large number of students and the instructor could answer their queries live, which is already well implemented for small groups using Skype and Zoom. Intriguingly, the online courses and virtual classes that are designed as per the regular academic curriculums of the institutes are serving very effectually during this COVID-19 shutdown.

\section{Virtual labs—simulating practical skills of science}

The regular e-learning courses alone cannot provide adequate skills or knowledge regarding laboratory experiments or analysis of scientific data. In this vein, the virtual labs added a new dimension to the web-based digital learning (Nilsson 2003; Huang 2004). Virtual labs are round-theclock available and an easily accessible simulated replica

of the real-life laboratories that can provide practical skills of science to the learners (Waldrop 2013b). Such simulated labs allow the learners to obtain knowledge regarding reallife experiments in a risk-free environment devoid of any direct physical contact with any toxic chemicals or pathogenic substances (Jones 2018). Table 1 summarises examples of a few selected virtual labs in different advanced areas of biological sciences (Table 1).

Virtual labs turning advantageous for educators since arranging expensive and sophisticated lab facilities in academic settings often remains challenging (Waldrop 2013b; Jones 2018), particularly in the developing and under-developed countries with limited educational budgets (Srivastava et al. 2013). A few years ago, we developed simulated labs on an advanced discipline of molecular biology (proteomics) and received excellent responses from the college and university students and early-stage researchers (Ray et al. 2012a, b). Of note, several studies indicate that there is no significant difference in learning outcomes between virtual and physical labs (Ray et al. 2016; Jong et al. 2013). Virtual labs can prepare a student or researcher better before they come for actual training or research in the laboratory and may serve as a pre-requisite for the lab-based courses which require handing of any expensive sophisticated analytical 
Table 1 Virtual labs and interactive e-learning resources in different advanced areas of biological sciences (Only a few selected prominent resources are exemplified here)

MIT Open Course Ware_Life Sciences, Massachusetts Institute of Technology, USA (https://ocw.mit.edu/courses/life-sciences/)

HHMI BioInteractive-Howard Hughes Medical Institute, USA (https://www.biointeractive.org/)

Virtual Mass Spectrometry Laboratory—Carnegie Mellon University, USA (https://svmsl.chem.cmu.edu/vmsl/default.htm)

Virtual Human Interaction Lab-Stanford University, USA (https://vhil.stanford.edu/)

Learn.Genetics-University of Utah, USA (https://learn.genetics.utah.edu/)

Analytical Sciences Digital Library—National Science Digital Library (https://www.asdlib.org/)

Virtual Biotechnology Engineering Labs—National Mission on Education, India (https://www.vlab.co.in/broad-area-biotechnology-and-biome dical-engineering)

Glencoe Virtual Labs (https://www.biologycorner.com/worksheets/virtual_labs_glencoe.html)

McGraw-Hill Biology Virtual Labs (https://www.mhhe.com/biosci/genbio/virtual_labs_2K8/)

The virtual laboratory-University College London, UK (https://www.ucl.ac.uk/ ucbcdab/simulations.htm)

instruments or toxic materials. Whether virtual labs can completely replace the real-life physical labs remains a matter of argument, but a combination of both is undoubtedly valued in science education (Jong et al. 2013).

Virtual labs could be useful resources for driving regular lab-based science education amid the COVID-19 lockdowns. Moreover, the students who are interested to gain knowledge beyond their respective academic courses or even the non-traditional learners can also play with these simulated experimental workflows for better and fruitful utilization of time during this lockdown phase.

\section{Lessons and future agenda}

With the current trend of the COVID-19 outbreak, returning of the students to the campus is turning very difficult in India and many other countries. Therefore, conducting scheduled examinations according to the regular timetable is also a formidable challenge. This pandemic has also taught us that the virtualization of education could be extended to conducting online examinations (even open-book examinations) and masters or doctoral defense seminars remotely. Many universities in India and abroad are implementing such initiatives so that the examination processes are not delayed substantially.

Although working from home is not an effective option for the scientists working on the different aspects of COVID19-from learning its pathogenesis to developing diagnostic and therapeutic innovation. Nevertheless, besides education, several high-end research activities on SARS-CoV-2 are also going on remotely from home using internet resources and virtual environment. Importantly, several informative manuscripts have been published amid COVID-19 where the entire work has been carried out during the lockdown utilizing e-resources, available databases, and through virtual meetings using diverse video conferencing platforms.
Leaving a very few top-tier ones, the majority of the educational institutes worldwide are struggling hard to overcome this sudden downturn that is affecting students' learning massively. This situation may keep continuing even longer as this COVID-19 may linger. Complete virtualization of the educational missions overnight is not an easy task. Therefore, a critical question arising whether we should spend more time, efforts, and resources in the virtualization of our daily science education courses in academics? Such initiatives will not only enhance the spread of high-quality education globally but also will support to circumvent such unusual calamities never seen before. Therefore, collaborative initiatives are essential to bringing together the expertise and resources both at the national and global levels to overcome this educational downturn amid COVID-19.

Acknowledgements SR is supported by the Perelman School of Medicine, University of Pennsylvania. SS acknowledges funding from the Ministry of Human Resource Development-India (10MHRD005 and 11MHRD005) for supporting the e-learning projects in his lab. Support from Mr. Shaik Khaja in preparation of the figure is acknowledged. The authors declare that they have no competing financial interests.

\section{References}

Anderson RM, Heesterbeek H, Klinkenberg D, Hollingsworth TD (2020) How will country-based mitigation measures influence the course of the COVID-19 epidemic? Lancet 395:931-934. https:// doi.org/10.1016/S0140-6736(20)30567-5

de Jong T, Linn MC, Zacharia ZC (2013) Physical and virtual laboratories in science and engineering education. Science 340:305-308. https://doi.org/10.1126/science. 1230579

DiCarlo SE (2006) Cell biology should be taught as science is practised. Nat Rev Mol Cell Biol 7:290-296. https://doi.org/10.1038/ nrm 1856

Emanuel EJ (2013) Online education: MOOCs taken by educated few. Nature 503:342. https://doi.org/10.1038/503342a

Hansen JD, Reich J (2015) Democratizing education? Examining access and usage patterns in massive open online courses. Science 350:1245-1248. https://doi.org/10.1126/science.aab3782 
Huang C (2004) Virtual labs: e-learning for tomorrow. PLoS Biol 2:e157. https://doi.org/10.1371/journal.pbio.0020157

Hunter P (2015) The virtual university: digital tools for e-learning and remote learning are becoming an increasingly important tool for teaching at universities. EMBO Rep 16:146-148. https://doi. org/10.15252/embr.201440016

Jones N (2018) Simulated labs are booming. Nature 562:S5-S7. https ://doi.org/10.1038/d41586-018-06831-1

King C, Robinson A, Vickers J (2014) Online education: targeted MOOC captivates students. Nature 505:26. https://doi. org/10.1038/505026a

Nilsson T (2003) Virtual laboratories in the life sciences. A new blueprint for reorganizing research at the European level. EMBO Rep 4:914-916. https://doi.org/10.1038/sj.embor.embor952

Ray S, Koshy NR, Diwakar S, Nair B, Srivastava S (2012a) Sakshat labs: India's virtual proteomics initiative. PLoS Biol 10:e1001353. https://doi.org/10.1371/journal.pbio.1001353

Ray S, Koshy NR, Reddy PJ, Srivastava S (2012b) Virtual labs in proteomics: new e-learning tools. J Proteom 75:2515-2525. https:// doi.org/10.1016/j.jprot.2012.03.014
Ray S, Srivastava S, Diwakar S, Nair B, Özdemir V (2016) Delivering on the promise of bioeconomy in the developing world: link it with social innovation and education. In: Srivastava S (ed) Biomarker discovery in the developing world: dissecting the pipeline for meeting the challenges. Springer India, New Delhi, pp 73-81. doi: 10.1007/978-81-322-2837-0_6

Srivastava S, Özdemir V, Ray S, Panga JR, Noronha S, Nair B et al (2013) Online education: e-learning booster in developing world. Nature 501:316. https://doi.org/10.1038/501316c

Waldrop MM (2013a) Online learning: Campus 2.0. Nature 495:160163. https://doi.org/10.1038/495160a

Waldrop MM (2013b) Education online: the virtual lab. Nature 499:268-270. https://doi.org/10.1038/499268a

Wood EJ (2001) Biochemistry and molecular biology teaching over the past 50 years. Nat Rev Mol Cell Biol 2:217-221. https://doi. org/10.1038/35056600 